\title{
IMPLEMENTASI PENDIDIKAN KARAKTER DALAM PEMBELAJ ARAN PAI DI MTSN 1 KOTA SAWAHLUNTO
}

\author{
Camberlin, Asmendri, Nurlaila \\ Guru MIN 1 Kota Sawahlunto \\ Desa Tumpuk Tangah Kecamatan Talawi Kota Sawahlunto \\ Alamat Sekolah Jl. Sawalunto Batusangkar Desa Talawi Mudik Kecamatan Talawi \\ e-mail: camberlinspdi@gmail.com
}

\begin{abstract}
This study aims to determine the forms of character education implementation in PAI learning at MTsN 1 in Sawahlunto City, to find out the process of implementing character education in PAI learning at Sawahlunto City MTsN 1, and to find out the obstacles faced in implementing character education in learning PAI at MTsN 1 in Sawahlunto City. Qualitative research methods, case study research. Research informants were the head of the madrasa, curriculum waka, and PAI teachers. Data collection tools are researchers as key instruments and supporting instruments are interview guidelines, observation guidelines, field notes, and recording devices. The data analysis technique uses models from Miles and Huberman, namely data reduction, data presentation, and conclusion drawing. The technique of testing the validity of the data uses data triangulation. The results of the study show that the forms of implementation of character education in PAI learning begin with planning that is structured systematically, then self-development. While the process of implementing character education runs in schools and outside. The obstacle faced in the application of character education in MTsN 1 in Sawahlunto City is the lack of teacher attention, the role of parents and association.
\end{abstract}

Keywords: Pendidikan Karakter, Pembelajaran PAI

\section{PENDAHULUAN}

Pendidikan merupakan hal yang sangat prinsip dalam kehidupan dan aset yang tak ternilai bagi individu dan masyarakat. Pendidikan penting bagi suatu bangsa, di mana pendidikan tersebut mencerminkan kepribadian dan kebudayaan bangsa itu sendiri. Tanpa pendidikan, bangsa tersebut tidak akan dapat maju, karena maju dan mundurnya suatu bangsa tergantung pada pendidikan. Pendidikanlah yang akan merubah nasib dan tingkah laku manusia baik pribadi maupun sebagai masyarakat ke arah yang lebih baik, dengan kata lain pendidikan itu memegang kedudukan penting pada manusia. 
Tanpa pendidikan, manusia itu akan mengalami ketidakstabilan dalam kehidupannya.

Pendidikan menurut Undangundang Nomor 20 tahun 2003 tentang Sistim Pendidikan Nasional (SPN), bab I pasal 1 adalah usaha sadar dan terencana untuk mewujudkan suasana belajar dan proses pembelajaran agar peserta didik secara aktif mengembangkan potensi dirinya untuk memiliki kekuatan spiritual keagamaan, pengendalian diri, kepribadian, kecerdasan, akhlak mulia, serta keterampilan yang diperlukan dirinya, masyarakat, bangsa dan negara (Departemen Agama RI, 2007: 5).

Sedangkan pendidikan nasional adalah pendidikan yang berdasarkan Pancasila dan Undang-Undang Dasar Nagara Republik Indonesia Tahun 1945 yang berakar pada nilai-nilai agama, kebudayaan nasional Indonesia dan tanggapan terhadap tuntutan perubahan zaman (Departemen Agama RI, 2007: 5).

Fungsi pendidikan nasional adalah mengembangkan kemampuan dan membentuk watak serta peradaban bangsa yang bermartabat dalam rangka mencerdaskan kehidupan bangsa. Sedangkan tujuan pendidikan nasional adalah untuk mengembangkan potensi peserta didik agar menjadi manusia yang beriman dan bertaqwa kepada Tuhan Yang Maha Esa, beraklak mulia, sehat, cakap, kreatif, mandiri, dan menjadi warga negara yang demokratis, serta bertanggung jawab (Departemen Agama RI, 2007: 5).

Tujuan pendidikan mengelompokkan tujuan pendidikan Islam pada tujuan umum dan tujuan khusus. Tujuan umum menjadikan manusia sebagai abdi dan hamba Allah SWT yang senantiasa mengagungkan dan membesarkan Asma Allah SWT dengan meneladani Rasulullah SAW, menjunjung tinggi ilmu pengetahuan suka mempelajari segala yang bermanfaat baginya dalam merealisasikan tujuan yang telah digariskan oleh Allah SWT.

Pendidikan karakter secara sederhana dapat diartikan sebagai pendidikan nilai, pendidikan watak, pendidikan moral, dan pendidikan budi pekerti yang bertujuan mengembangkan kompetensi peserta didik untuk mewujudkan kebaikan dalam kehidupan sehari-hari dengan sepenuh hati (Bukhari 2012: 33). Oleh karena itu dari pemaknaan tersebut maka dapat dipahami bahwa pendidikan karakter merupakan suatu sistem penanaman nilai-nilai karakter kepada warga sekolah yang meliputi komponen pengetahuan, kesadaran atau kemauan, dan tindakan untuk melaksanakan nilai-nilai tersebut. Sehingga dalam pendidikan karakter di sekolah, semua komponen (pemangku pendidikan) harus terlibat, tersebut komponen-komponen pendidikan itu sendiri, yaitu isi 
kurikulum, proses pembelajaran dan penilaian, penanganan atau pengelolaan mata pelajaran, pengelolaan sekolah, pelaksanaan aktivitas atau kegiatan ekstrakurikuler, pemberdayaan sarana dan prasarana, pembiayaan dan etos kerja seluruh warga sekolah (Wibowo, 2012: 36).

Hakikat pendidikan karakter dalam konteks pendidikan di Indonesia dapat dimaknai sebagai nilai, yaitu pendidikan nilai-nilai luhur yang bersumber dari budaya bangsa Indonesia sendiri, dalam rangka membina akhlak generasi muda. Penguatan moral (moral education) atau pendidikan karakter (caracter education) secara formal dalam sistem pendidikan nasional bukanlah suatu hal yang baru lagi, karena sesungguhnya dalam pembentukan karakter telah menjadi salah satu tujuan pendidik nasional, di mana pada pasal 3 UndangUndang Sisdiknas tahun 2003 menyatakan bahwa diantara tujuan pendidikan nasional adalah mengembangkan potensi peserta didik agar menjadi manusia yang beriman dan bertaqwa kepada Tuhan Yang Maha Esa, berakhlak mulia, sehat, berilmu, cakap, kreatif, mandiri dan menjadi warga negara yang demokratis serta bertanggung jawab (UU No. 20 Tahun 2003: 8-9).

Guru adalah orang yang bertanggung jawab mencerdaskan kehidupan anak didik. Pribadi susila yang cukup adalah yang diharapkan ada pada diri setiap anak didik, tidak ada seorang guru pun yang mengharapkan anak didiknya menjadi sampah masyarakat. Untuk itulah guru dengan penuh dedikasi dan loyalitas berusaha membimbing dan membina anak didiknya agar di masa mendatang menjadi orang yang berguna bagi nusa dan bangsa (Uhbiyati, 2012: 65).

Di MTsN 1 kota Sawahlunto, nilai-nilai karakter menjadi prioritas untuk di tingkatkan karena MTsN 1 Kota Sawahlunto merupakan suatu lembaga pendidikan Islam di bawah pengawasan Kementerian Agama Kota Sawahlunto dan hendaknya menjadi contoh baik bagi sekolahsekolah lain tentang karakter baik dari sisi pendidik maupun peserta didik. Menurut pengamatan peneliti, dalam hal pendidikan karakter, MTsN 1 Kota Sawahlunto terus menggali seluruh potensi peserta didik yang dalam tataran pelaksanaannya dalam kondisi yang menyenangkan pada setiap mata pelajaran dan pada setiap kegiatan pembelajaran dengan mengintegrasikan nilai-nilai kehidupan beragama sebagai pembentukan karakter, seperti: budaya hidup bersih, budaya $5 S$ (senyum, sapa, salam, sopan dan santun), tertib berkedaraan, serta memiliki jiwa sosial yang baik (Observasi Awal, Senin 5 Februari 2018). 
KAJIAN TEORI

\section{Konsep Pendidikan Karakter}

Kata character berasal dari bahasa Yunani charassein, yang berarti to engrave (melukis, menggambar), seperti orang yang melukis kertas, memahat batu atau metal. Berakar dari pengertian yang seperti itu, character kemudian diartikan sebagai tanda atau ciri yang khusus, dan karenanya melahirkan suatu pandangan bahwa karakter adalah pola perilaku yang bersifat individual, keadaan moral seseorang.

Karakter yang baik berkaitan dengan mengetahui yang baik (knowing the good), mencintai yang baik (loving the good), dan melakukan yang baik (acting the good). Ketiga ideal ini satu sama lain sangat berkaitan. Seseorang lahir dalam keadaan bodoh, dorongan-dorongan primitif yang ada dalam dirinya kemungkinan dapat memerintahkan atau menguasai akal sehatnya. Maka, efek yang mengiringi pola pengasuhan dan pendidikan seseorang akan dapat mengarahkan kecenderungan, perasaan, dan nafsu besar menjadi beriringan secara harmoni atas bimbingan akal dan juga ajaran agama (Sutdrajat, 2011: 2).

Hidayatullah (2010: 12) yang mengemukakan bahwa karakter berasal dari akar kata bahasa latin yang berarti dipahat. Sebuah kehidupan, seperti sebuah blok granit dengan hati-hati dipahat atau pun dipukul secara sembarangan yang pada akhirnya akan menjadi sebuah mahakarya atau puing-puing yang rusak. Karakter, gabungan dari kebajikan dan nilai-nilai yang dipahat di dalam batu hidup tersebut, akan menyatakan nilai yang sebenarnya.

Koesoema (2010: 90) memahami bahwa istilah karakter, berasal dari bahasa Yunani "karasso", berarti cetak biru, format dasar. Ia melihat ada dua makna interpretasi dari karakter, yaitu pertama, sebagai kumpulan kondisi yang telah diberikan begitu saja, atau telah ada begitu saja, yang lebih kurang dipaksakan dalam diri kita. Karakter yang demikian dianggap sebagai sesuatu yang telah ada dari sononya (given).Kedua, karakter juga bisa dipahami sebagai tingkat kekuatan melalui mana seseorang individu mampu menguasai kondisi tersebut. Karakter yang demikian ini disebutnya sebagai sebuah proses yang dikehendaki.

Pendidikan Karakter menurut Megawangi (2007: 93) adalah sebuah usaha untuk mendidik anak-anak agar dapat mengambil keputusan dengan bijak dan mengaplikasikan hal tersebut dalam kehidupan sehariharinya, sehingga mereka dapat memberikan sumbangsih yang positif kepada lingkungan sekitarnya. Nilainilai karakter yang perlu ditanamkan kepada anak-anak adalah nilai-nilai universal yang mana seluruh agama, 
tradisi, dan budaya pasti menjunjung tinggi nila-nilai tersebut. Nilai-nilai universal ini harus dapat menjadi perekat bagi seluruh anggota masyarakat walaupun berbeda latar belakang budaya, suku, dan agama.

$$
\text { Menurut Gaffar (2010: }
$$
pendidikan karakter adalah sebuah proses tranformasi nilai-nilai kehidupan kehidupan untuk di tumbuhkembangkan dalam keperibadian seseorang sehingga menjadi satu dalam perilaku kehidupan orang itu. Dalam definisi tersebut ada tiga ide pikiran penting, yaitu: 1) proses transformasi nilai-nilai, 2) ditumbuh kembangkan dalam kepribadian, dan 3) menjadi satu dalam perilaku.

\section{Latif (2007: 40) mengutip}

Thomas Lickona yang mengatakan bahwa pendidikan karakter adalah usaha sengaja untuk menolong orang agar memahami, peduli akan, dan bertindak atas dasar nilai-nilai etis. Lickona menegaskan bahwa tatkala kita berpikir tentang bentuk karakter yang ingin ditunjukkan oleh anakanak, teramat jelas bahwa kita menghendaki mereka mampu menilai apa yang benar, peduli tentang apa yang benar, serta melakukan apa yang diyakini benar, bahkan ketika menghadapi tekanan dari luar dan godaan dari dalam.

Pendidikan karakter pada hakikatnya merupakan pengintegrasian antara kecerdasan, kepribadian, dan akhlak mulia. Pendidikan karakter menurut Thomas Lichona merupakan media pembantu bagi peserta didik untuk memahami, peduli, dan berbuat atau bertindak berdasarkan nilai-nilai etika. Sejalan dengan itu, Suyanto menegaskan bahwa pendidikan karakter adalah pendidikan budi pekerti plus, yaitu melibatkan aspek pengetahuan (cognetive), perasaan (feeling) dan tindakan (action) (Anwas, 2010: 4). Menurut penulis pendidikan karakter adalah suatu sistem penanaman nilai-nilai karakter kepada warga sekolah yang meliputi komponen pengetahuan, kesadaran atau kemauan, dan tindakan untuk melaksanakan nilai-nilai tersebut.

\section{Kepala Sekolah}

Pendidikan secara etimologi berasa dari bahasa Yunani yang terdiri dari kata "Pais" artinya seseorang, dan "again" diterjemahkan membimbing. Jadi pendidikan (paedogogie) artinya bimbingan yang diberikan pada seseorang. Sedangkan secara umum pendidikan merupakan bimbingan secara sadar oleh pendidik terhadap perkembangan jasmani dan rohani peserta didik menuju terbentuknya kepribadian yang utama. Oleh karena itu, pendidikan dipandang sebagai salah satu aspek yang memiliki peranan pokok dalam membentuk generasi muda agar memiliki kepribadian yang utama (Ahmadi dan Uhbiyati, 2006: 69). 
Jadi pengertian pendidikan secara harfiah berarti membimbing, memperbaiki, menguasai, memimpin, menjaga, dan memelihara. Esensi dari pendidikan adalah adanya proses transfer nilai, pengetahuan, dan keterampilan dari generasi tua kepada generasi muda agar generasi muda mampu hidup. Oleh karena itu, ketika kita menyebut pendidikan agama Islam, maka akan mencakup dua hal, yaitu: a) Mendidik peserta didik untuk berperilaku sesuai dengan nilai-nilai atau akhlak Islam b) Mendidik peserta didik untuk mempelajari materi ajaran agama Islam.

Dengan demikian, maka pengertian pendidikan agama Islam berdasarkan rumusan-rumusan di atas adalah pembentukan perubahan sikap dan tingkah laku sesuai dengan petunjuk ajaran agama Islam. Sebagaimana yang pernah dilakukan Nabi dalam usaha menyampaikan seruan agama dengan berdakwah, menyampaikan ajaran, memberi contoh, melatih keterampilan berbuat, memberi motivasi dan menciptakan lingkungan sosial yang mendukung pelaksanaan ide pembentukan pribadi muslim. Untuk itu perlu adanya usaha, kegiatan, cara, alat, dan lingkungan hidup yang menunjang keberhasilannya.

Dari keterangan di atas dapat penulis simpulkan bahwa agama adalah peraturan yang bersumber dari
Allah SWT, yang berfungsi untuk mengatur kehidupan manusia, baik hubungan manusia dengan sang pencipta, maupun hubungan antara sesamanya yang dilandasi dengan harapan ridho Allah SWT untuk mencapai kebahagian hidup di dunia dan akhirat.

\section{METODE PENELITIAN}

Penelitian ini mengunakan pendekatan kualitatif, salah satu jenis penelitian kualitatif adalah berupa penelitian dengan metode atau pendekatan studi kasus (Case Study). Studi kasus termasuk dalam penelitian analisis deskriptif, yaitu penelitian yang dilakukan terfokus pada suatu kasus tertentu untuk diamati dan dianalisis secara cermat sampai tuntas. Kasus yang dimaksud bisa berupa tunggal atau jamak, misalnya berupa individu atau kelompok. Di sini perlu dilakukan analisis secara tajam terhadap berbagai faktor yang terkait dengan kasus tersebut sehingga akhirnya akan diperoleh kesimpulan yang akurat.

Dalam penelitian kualitatif instrumen penelitian adalah peneliti sendiri yang menjadi instrumen kunci atau utama yang mengumpulkan data berdasarkan kriteria-kriteria yang dipahami. Instrumen pendukung pada penelitian ini adalah menggunakan pedoman observasi dan pedoman wawancara serta alat 
lainnya. Sumber data dalam penelitian ini ada 6 orang dengan mengunakan teknik pengumpulan data yaitu: observasi, wawancara dan dokumentasi.

Dalam analisis data pada penelitian mengikuti model Analisis data yang digunakan analysis interaktif model dari Miles dan Huberman yang membagi kegiatan analisis menjadi empat bagian, yaitu pengumpulan data, reduksi data, penyajian data, dan penarikan kesimpulan atau verifikasi data.

\section{HASIL DAN PEMBAHASAN}

\section{Hasil Penelitian}

a. Bentuk-Bentuk Implementasi Pendidikan Karakter pada Pembelajaran PAI di MTsN 1 Kota Sawahlunto

1) Perencanaan Pendidikan Karakter dalam Pembelajaran PAI

Perencanaan pembelajaran PAI di MTsN 1 Kota Sawahlunto tersusun secara sistematis, hal ini ditunjukkan dengan rencana pelaksanaan pembelajaran yang sudah didesain mengacu pada pendidikan karakter ini tercatum dalam KI 1 yang bertujuan untuk menghayati dan mengamalkan ajaran agama yang dianut oleh peserta didik, hal ini menunjukkan adanya proses pendidikan karakter agar siswa menjadi religius. Maka selanjutnya pada KI 2 telah dicantumkan lebih dari pada implementasi pendidikan karakter dalam hal sosial yakni mengembangkan perilaku jujur, disiplin, tanggung jawab, peduli, santun, ramah lingkungan, gotong royong, kerjasama dan cinta damai. Hal ini menunjukkan bahwa konsep pembelajaran PAI ini sudah diarahkan agar peserta didik berkarakter yang pandai bergaul dalam kehidupan dan disiplin dalam keseharian.

Kemudian dipaparkan pula RPP pada KI 3 yang berisi pemahaman dan menerapkan pengetahuan faktual, konsep, prosedur dalam ilmu pengentahuan, teknologi, seni dan budaya dan wawasan kemanusiaan, bangsaaan, kenegaraan dan peradaban. Dengan harapan pendidikan karakter menjadikan siswa insan yang cerdas. KI 4 dalam RPP mata pelajaran PAI (meliputi: Fiqih, Aqidah, Al Qur'an Hadits, dan Sejarah Kebudayaan Islam) berisi mengolah, menalar, dan menyajikan dalam ranah konkrit dan ranah abstrak terkait dengan pengembangan dari yang dipelajarinya di sekolah secara mandiri maupun mengunakan metode sesuai dengan kaidah keilmuan dengan tujuan agar peserta didik memiliki karakter skill (keterampilan) yang baik. 
2) Pelaksanaan Pendidikan Karakter dalam Pembelajaran PAI

Sedangkan pelaksanaan implementasi pendidikan karakter di MTsN 1 Kota Sawahlunto dalam proses pembelajaran di kelas pada mata pelajaran Aqidah Akhlak berlangsung guru memulai dengan mengucapkan salam, peserta didik berdo'a, membaca beberapa surat pendek, membaca asmaul husna secara bersama-sama. Kemudian guru membuka awal pembelajaran pada tahap pelaksanaan dengan 5 unsur sebagai berikut: 1) mengamati, guru membagi siswa empat kelompok dan membagi topik yang berbeda kepada masing-masing kelompok, guru mempersilahkan siswa untuk membaca dan mengamati sesuai dengan tema ditentukan dengan tujuan masingmasing kelompok mampu menyampaikan, 2) menanya, pada saat berdiskusi mengalami masalah, maka siswa disilahkan bertanya pada teman lain atau bertanya kepada guru, 3) mengeksplorasikan, atau mengumpulkan data, yakni masing-masing kelompok bagaimana cara memerankan topik mulai membagi karakter dalam peran masingmasing topik tersebut, 4) mengasosiasi, setiap siswa diminta untuk mengkaitkan materi yang didiskusikan dengan kehidupan sehari-hari, mengkomunikasikan, setiap kelompok mendemonstrasikan masingmasing peran sesuai dengan materi.

3) Evaluasi Pendidikan Karakter dalam Pembelajaran PAI

Evaluasi pendidikan karakter dalam pembelajaran PAI merupakan suatu hal yang sangat penting untuk melihat sejauh mana keberhasilan dalam proses pembelajaran PAI tentang implementasi pendidikan karakter di MTsN 1 Kota Sawahlunto.

4) Program pendukung pendidikan karakter dalam pembelajaran pai pengembangan diri, seperti: program tahfiz, shalat zuhur berjama'ah, zikir dan do'a, dan tahsin Alquran.

\section{b. Proses Implementasi Pendidikan Karakter pada Mata Pelajaran PAI di MTsN 1 Kota Sawahlunto}

Pada dasarnya bahwa setiap guru memiliki harapan tersendiri akan perkembangan peserta didiknya, berbagai tujuan dan upaya pun dilakukan untuk mencapai upaya tersebut, seperti sejalan dengan visi yaitu mewujudkan insan yang bertaqwa, cerdas, kreatif dan berbudaya dan misi MTsN 1 kota Sawahlunto. Dalam hal ini upaya pendidikan karakter pada peserta didik merupakan salah satu hal yang wajib dilaksanakan di madrasah, bahwa segala sesuatu yang dilakukan 
oleh guru harus mampu mempengaruhi karakter peserta didik. Maka sebagai pembentuk watak peserta didik, guru harus menunjukkan keteladanan berprilaku karna guru merupakan contoh bagi peserta didik.

Karakter disiplin juga dilihat dari keseharian peserta didik di MTsN 1 Kota Sawahlunto dengan selalu hadir tepat waktu ke sekolah yakni pukul 06.30 WIB, karakter religius juga terlihat pada saat siswa melaksanakan shalat dhuha, shalat Zuhur berjamaah dan membaca ayat Al-Qur'an sebelum pembelajaran dimulai. Adapun karakter cerdas ditunjukkan dengan kemampuan peserta didik yang cepat tanggap dan aktif dalam kegiatan belajar mengajar di kelas, suka bertanya juga karakter yang didapatkan dari rasa ingin tahu peserta didik dalam diskusi di kelas.

\section{c. Kendala dalam Implementasi Pendidikan Karakter pada Mata Pelajaran PAI di MTsN 1 Kota Sawahlunto}

Kendala atau penghambat yang diperoleh dari observasi dan wawancara yang peneliti lakukan di MTsN 1 Kota Sawahlunto, menunjukkan bahwa yang menjadi kendala dalam implementasi pendidikan karakter pada mata pelajaran PAI yakni kurangnya perhatian guru kepada siswa di luar lingkungan sekolah. Dapat pahami bahwa yang menjadi kendala dalam implementasi pendidikan karakter pada mata pelajaran PAI di MTsN 1 Kota Sawahlunto, sebagai berikut: 1) kurangnya perhatian sebagian guru terhadap siswa, 2) peran orang tua yang belum maksimal dalam mendidik anak, dan 3) lingkungan pergaulan siswa di luar sekolah.

\section{Pembahasan}

\section{a. Bentuk-Bentuk Implementasi} Pendidikan Karakter pada Pembelajaran PAI di MTsN 1 Kota Sawahlunto

1) Perencanaan Pendidikan Karakter dalam Pembelajaran PAI

Pendidikan merupakan suatu proses pembelajaran yang dilaksanakan secara sistematis oleh pendidik kepada peserta didik dalam hal membimbing, memperbaiki, menguasai, memimpin dan memajukan pertumbuhan jasmani dan rohani peserta didik untuk menuju pribadi yang utama. Bahwa penting sekali dalam hal ini setiap anak harus memperoleh hak atas pendidikannya sejak dini, seperti kita ketahui orang tua mendidik anaknya di rumah dengan sebaikbaik metode yang diterapkan masing-masing keluarga, tetapi di luar dari pada itu seorang anak harus juga memperoleh pendidikan baik di madrasah maupun di madrasah yang dapat memberikan pengajaran lebih banyak dan 
berharga bagi perkembangan anak tersebut (Koesoema, 2012: 218).

Perhatian yang menyeluruh atas perkembangan anak dalam berbagai hal seperti perkembangan kognitif, sosial, agama, maupun efektif atau prilaku keseharian. Berhubungan dengan hal yang demikian madrasah merupakan tempat ke dua bagi anak untuk memcapai tujuan tersebut karena madrasahlah untuk mendidik insan yang berkarakter. Dalam hal ini pendidikan karakter merupakan pembelajaran yang mengarah pada penguatan dan pengembangan anak secara utuh yang didasarkan pada nilai tertentu yang ditunjuk oleh sekolah atau madrasah maka hal ini mengandung makna bahwa karakter merupakan pendidikan yang terintegrasi dengan pembelajaran yang terjadi pada semua mata pelajaran di madrasah, sehingga diarahkan pada penguatan dan pengembangan prilaku anak secara utuh, berkenaan dengan tersebut implementasi pendidikan karakter pada mata pelajaran PAI sangat perlu sekali terlaksana dengan baik.

2) Pelaksanaan Pendidikan Karakter dalam Pembelajaran PAI

Dalam pembahasan penelitian implementasi pendidikan karakter pada mata pelajaran PAI di MTsN 1 Kota Sawahlunto ini bahwa terdapat pelaksanaan kegiatan belajar mengajar PAI yang baik dan sistematis di madrasah ini, pasalnya karena setiap guru PAI baik guru mengapu mata pelajara Fiqh, Al Qur'an Hadits, Aqidah Akhlak dan Sejarah Kebudayaan Islam yang ada di madrasah ini sangat memperhatikan isi materi yang sudah disusun sesuai dengan kurikulum dan menyampaikan mata pelajaran PAI di kelas dengan persiapan dan metode strategi pembelajaran tersendiri secara baik dan tidak menyampingkan implementasi nilai-nilai karakter yang terkandung di dalam mata pelajaran PAI itu sendiri.

3) Evaluasi Pendidikan Karakter dalam Pembelajaran PAI

Evaluasi pendidikan karakter dalam pembelajaran PAI merupakan suatu hal yang perlu untuk dilihat sejauh mana keberhasilan dalam proses pembelajaran PAI tentang implementasi pendidikan karakter di MTsN 1 Kota Sawahlunto. Kegiatan evaluasi ini telah dilaksanakan di MTsN 1 Kota Sawahlunto setiap tengah semester, semester dan juga dalam bentuk ujian harian. Bentuk yang telah dilaksanakan di MTsN 1 Kota Sawahlunto berupa tes tertulis dan lisan yang bertujuan untuk menilai kemampuan kognitif, afektif dan psikomotor siswa baik dalam proses pembelajaran maupun di luar PBM.

Sudjana (2002: 30) menjelaskan evaluasi merupakan sebuah proses pengumpulan data untuk menentu-

\section{2 | Jurnal el-Hekam, Vol. IV, No. 1, Januari-Juni 2019}


kan sejauh mana, dalam hal apa, dan bagian mana tujuan pendidikan sudah tercapai, evaluasi dalam proses pembelajaran harus mengacu pada tiga domain yang melekat pada diri peserta didik yaitu: ranah proses berfikir (cognitive domain), ranah nilai atau sikap (affective domain), dan ranah keterampilan (psychomotor domain).

4) Program Pendukung Pendidikan Karakter dalam Pembelajaran PAI (Pengembangan Diri)

a) Tahfiz

Program Tahfiz di MTsN 1 Kota Sawahlunto adalah suatu kegiatan dalam pengembangan bakat peserta didik dengan tujuan untuk menjadi anak-anak penghafal al-Qur'an dan mampu mengamalkan isi kandungan ayat-ayat Al-Qur'an dalam kehidupan sehari-hari, mendidikan jiwa menjadi tenang, bisa lebih dekat dengan al-Qur'an, dan dapat terhindar dari pengaruh negatif. Memang sudah diadakan program Tahfiz yang merupakan kegiatan ekstrakurikuler di MTsN 1 Kota Sawahlunto yang dilaksanakan dua kali seminggu, yaitu setiap hari Senin dan Kamis selesai shalat Zuhur sampai jam 15.00 wib yang tempatnya di ruangan kelas masing-masing.

b) Shalat zuhur berjama'ah

Dalam aplikasikan shalat zuhur di MTsN 1 Kota Sawahlunto, siswa melaksanakan shalat secara berjamaah. Setelah shalat selesai, kemudian diikuti wirid dan doa bersama, shalat Zuhur diimami oleh salah seorang dari guru dan adzan dilakukan oleh siswa. Shalat Zuhur dilaksanakan secara berjamaah. Adapun shalat berjamaah hukumnya sunnah muakkad (sangat dianjurkan). Sedangkan tujuannya untuk mendidik siswa disiplin dengan waktu khusus dengan waktu shalat dan mempererat hubungan silaturrahmi serta mendidik siswa untuk selalu patuh dan taat terhadap aturan.

c) Zikir dan do'a

Kegiatan zikir dan do'a telah dilaksanakan di MTsN 1 Kota Sawahlunto, yang mana pelaksanaannya yaitu setiap selesai shalat zuhur yang dipimpin oleh seorang imam dan diikuti secara bersamasama. Dengan tujuan mendidik anak supaya terbiasa untuk mengingat Allah dan terhindar dari gangguan hal-hal gaib atau jin.

d) Tahsin Al-qur'an

Tahsin al-Qur'an telah menjadi kegiatan rutin juga di MTsN 1 Kota Sawahlunto. Membaca al-Qur'an ini dilkukan setelah pulang sekolah setiap hari rabu jam 13.30-15.00 wib. Siswa membaca ayat alQur'an, setelah itu guru pembimbing membenarkan bacaan bagi siswa yang belum bisa secara bergiliran. Sedangkan bagi siswa yang lain menyimak dan men- 
dengarkan dengan baik, walaupun belum sesuai dengan adab dalam membaca al-Qur'an tersebut. Dampak dari kegiatan tahsin alQur'an terhadap pendidikan karakter yang telah dilaksanakan di MTsN 1 Kota Sawahlunto, di antaranya: jiwa tenang, bacaan alQur'an bagus, dan mendidik siswa untuk saling menghargai serta menumbuhkan jiwa sosial.

\section{b. Proses Implementasi Pendidikan} Karakter pada Mata Pelajaran PAI di MTsN 1 Kota Sawahlunto

Dalam proses implementasi pendidikan karakter di MTsN 1 Kota Sawahlunto, bahwa segala sesuatu yang dilakukan guru harus mampu mempengaruhi peserta didik, seorang guru harus menunjukkan keteladanan kemudian hendaknya setiap prilaku guru menjadi contoh bagi semua peserta didik, misalnya, cara guru berbicara, berbusana, menyampaikan materi, toleransi, dan berbagai hal lainya, dengan tujuan adalah membentuk pribadi anak atau peserta didik agar menjadi manusia yang baik, masyarakat yang baik, dan warga negara yang baik.

Metode ini bisa menjadi unsur-unsur yang sangat penting bagi sebuah proyek pendidikan karakter di sekolah. Pendidikan karakter yang mengakarkan dirinya pada konteks sekolah akan mampu menjiwai dan mengarahkan sekolah pada penghayatan pendidikan karakter yang realistis, konsisten, dan integral. Ada lima metode pendidikan karakter yang bisa kita terapkan dalam sekolah sebagai berikut: mengajarkan, keteladanan, menentukan prioritas, praktis prioritas, serta refleksi (Koesoema, 2010: 212).

\section{c. Kendala dalam Implementasi} Pendidikan Karakter pada Mata Pelajaran PAI di MTsN 1 Kota Sawahlunto

Kendala atau penghambat yang diperoleh dari observasi dan wawancara yang peneliti lakukan di MTsN 1 Kota Sawahlunto, menunjukkan bahwa yang menjadi kendala dalam implementasi pendidikan karakter pada mata pelajaran PAI yakni kurangnya perhatian guru kepada siswa di luar lingkungan madrasah bahwa memelihara karakternya itu, anakanak itu bermacam-macam tingkah lakunya, ada yang patuh dan ada yang nakal dan lain-lain, tetapi kita selaku guru harus tetap saja mendidiknya, kalau di MTsN 1 Kota Sawahlunto ini yang sangat terlihat oleh saya tentang kendala dalam implemtasikan pendidikan karakter ini adalah masih ada sebagaian guru yang tak peduli terhadap karakter peserta didiknya, sehingga ada anak yang melanggar aturan sekolah kadang dibiarkan pak, namun ada juga guru yang sangat peduli terhadap karakter peserta didiknya dalam kehidupannya sehari-hari, karna guru ini kan juga punya kerterbatasan dalam mendidik apalagi di luar jam 
sekolah, namun kami kita selaku guru terus berdo'a dan menanamkan nilai-nilai keagamaan kepada mereka terutama dalam proses pembelajaran di kelas.

Menurut Muslich (2011: 26) paling tidak ada empat hambatan utama pembelajaran nilai di sekolah yaitu (1) masih kukuhnya pengaruh paham behaviorisme dalam sistem pendidikan di Indonesia sehingga keberhasilan belajar hanya diukur dari atributatribut luar dalam bentuk perubahan tingkah laku, (2) kapasitas pendidik dalam mengangkat struktur masih relatif rendah, (3) tuntutan zaman yang semakin praktis, (4) sikap yang kurangan menguntungkan bagi pendidikan. Meskipun telah teridentifikasi ada berbagai hambatan pembelajaran nilai di sekolah, kemudian ada juga faktor pendorong seperti: pengalaman pra sekolah, tingkat kecerdasan, kreativitas, motivasi belajar, dan kebiasaan belajar.

\section{PENUTUP}

\section{Kesimpulan}

Setelah melakukan kajian teoritis dan analisis data berdasarkan temuan di lapangan mengenai implementasi pendidikan karakter pada mata pelajaran PAI di MTsN 1 Kota Sawahlunto, maka dapat disimpulkan bahwa bentuk-bentuk implementasi pendidikan karakter pada pembelajaran PAI di MTsN 1 Kota Sawahlunto diawali dengan perencanaan pembelajaran tersusun secara sistematis, hal ini ditunjukkan dengan
Rencana Pelaksanaan Pembelajaran (RPP) yang berorientasi pada pembentukan karakter ini tercatum dalam KI 1 yang bertujuan untuk menghayati dan mengamalkan ajaran agama yang dianut oleh peserta didik. Proses implementasi pendidikan karakter pada mata pelajaran PAI di MTsN 1 Kota Sawahlunto, yang dimuat dalam KI 1 dan KI 2 berlangsung dalam KBM dan di luar KBM. Kemudian kendala dalam implementasi pendidikan karakter pada mata pelajaran PAI di MTsN 1 Kota Sawahlunto, sebagai berikut: 1) belum maksimalnya implementasi pendidikan karakter dari guru terhadap siswa, 2) kurang sinerginya implementasi pendidikan karakter di madrasah dengan keluarga, 3) pengaruh pergaulan siswa di luar madrasah yang belum mendukung terhadap pendidikan karakter.

\section{Saran}

Berdasarkan kesimpulan yang telah dikemukan, maka penulis menyampaikan beberapa saran sebagai berikut:

1. Hendaknya implementasi pendidikan karakter pada mata pelajaran di MTsN 1 Kota Sawahlunto diharapkan tidak hanya dilaksanakan oleh guru-guru mata pelajaran PAI saja tapi juga dilaksanakan oleh guru-guru mata pelajaran umum.

2. Guru mata pelajaran PAI di MTsN 1 Kota Sawahlunto (Fiqih, Akidah Akhlak, Qur'an Hadits, serta SKI) sebagai figur di madrasah harus dapat menjadi tauladan bagi peserta didik, baik di dalam 
lingkungan madrasah maupun di luar madrasah.

3. Orang tua sebagai wali peserta didik haruslah lebih bijak dalam membimbing dan mendidik anaknya, pemantau pergaulan anak, dengan harapan peserta didik tetap menjadi pribadi yang berkarakter mulia baik di sekolah maupun di lingkungan masyarakat.

4. Diharapkan kepada peneliti selanjutnya untuk meneliti tentang implementasi pendidikan karakter guru di MTsN 1 Kota Sawahlunto.

\section{KEPUSTAKAAN ACUAN}

Ahmadi, A. dan Uhbiyati, N. (2006). Ilmu Pendidikan. Jakarta: Rineka Cipta.

Anwas, M. (2010). Televisi Mendidik Karakter Bangsa: Harapan dan Tantangan, Jurnal Pendidikan dan Kebudayaan Volume 16 Edisi III, Oktober 2010, Balitbang Kementerian Pendidikan Nasional.

Bukhari. (2012). Guru Kunci Pendidikan Nasional. Yogyakarta: Leutika Prio.

Departemen Agama RI. (2007). AlQur'an dan Terjemahan. Bandung: CV Penerbit J-Art.

Gaffar M F. (2010) Pendidikan Karakter Berbasis Islam Jogjakarta: Karya Ilmiah Pendidikan Karakter Berbasis Agama. Edisi Agustus.
Hidayatullah, M. F. (2010). Pendidikan Karakter Membangu Peradaban Bangsa. Surakarta: Yuma Pustaka.

Koesoema, D. (2010). Pendidikan Karakter: Strategi Mendidik Anak Di Zaman Global. Jakarta: Grasindo.

Latif, Y. Hancurnya Karakter Hancurnya Bangsa, Urgensi Pendidikan Karakter. dalam Majalah Basis, Edisi Juli-Agustus 2007.

Megawangi, R. (2007). Pendidikan Karakter Solusi Yang Tepat Untuk Membangun Bangsa. Jakarta: Indonesia Heritage Foundation.

Muslich, M. (2011). Pendidikan Karakter Menjawab Tantangan Krisis Multidimensional. Jakarta: Bumi Aksara.

Sudjana, N. (2002). Penilaian Hasil Belajar Mengajar. Bandung: Remaja Rosdakarya.

Uhbiyati, N. (2012). Dasar-dasar Ilmu Pendidikan Islam. Semarang: Fakultas Tarbiyah IAIN Walisongo.

Undang-Undang No. 20 Tahun 2003 Tentang Sistem Pendidikan Nasional, 2006.

Wibowo, A. (2012). Pendidikan Karakter Strategi Membangun Karakter Bangsa Berperadaban. Yogyakarta: Pustaka Pelajar. 